\title{
An Analysis of the Practical Path of Innovation and Entrepreneurship Values of College Students in the New Era
}

\author{
Chiping Li \\ Hua Li College, Guangdong University of Technology \\ Guangzhou, Guangdong, China 511325
}

\author{
Lingli Mao* \\ Guangzhou Huali Science And Technology Vocational \\ College Guangzhou, Guangdong, China 511325
}

\author{
Zhiyong $\mathrm{He}$ \\ Hua Li College, Guangdong University of Technology \\ Guangzhou, Guangdong, China 511325
}

\begin{abstract}
The government advocates "mass entrepreneurship and innovation" to encourage and support university students in the new era to innovate and start businesses. College students are in full swing in the process of innovation and entrepreneurship, but there are often some difficulties, such as grasping the direction of uncertainty. Therefore, college students' innovation and entrepreneurship needs to be guided by correct entrepreneurial values and the problem of lack of entrepreneurial values education should be solved. This paper studies the practical path of innovation and entrepreneurship values of college students in the new era. From the four aspects of the central deployment of top-level design, the overall government advocacy plan, the implementation of colleges and universities, and the active innovation and entrepreneurship of students, it studies how to guide college students to establish correct entrepreneurial values. We will better promote innovation and entrepreneurship and make our due contribution to the country's social development.
\end{abstract}

Keywords-A new era; Innovation and entrepreneurship; Values; Practice path

\section{INTRODUCTION}

Cultivating and practicing the core socialist values is a strategic task for advancing the great cause of socialism with Chinese characteristics and realizing the Chinese dream of great rejuvenation of the Chinese nation. The Party and the national government advocate the active cultivation and practice of the core socialist values. Universities and colleges should pay special attention to the education of the core socialist values in the group of college students, adhere to the principle of education and moral education, and implement the fundamental tasks of the Li Deshu people. At the same time, the government advocates "mass entrepreneurship and innovation", especially encouraging and supporting college students in the new era to carry out innovation and entrepreneurship, and also attaches great importance to the education of innovative entrepreneurship among college

Phased Achievements of Guangdong Educational Science Research

Project "Ideological and Political Theory Education Synergy under

Dynamic and Complex Vision" (Project No. 2014GXJK178). students. In the process of innovation and entrepreneurship, college students often have some difficulties and can not grasp the direction. Therefore, college students 'innovation and entrepreneurship needs to be guided by correct entrepreneurial values, especially the fundamental views and value judgments of college students on entrepreneurship under the socialist system, which involves the fundamental value orientation of why to start a business, who to start a business, and how to start a business. In this paper, the new era of college students entrepreneurial values practice path research, from different levels in order to guide college students to establish a correct entrepreneurial values, better promote innovation and entrepreneurship follow the direction of national social development to make due contributions.

\section{Central Deployment Top LeVEl Design}

The report of the 18th National Party Congress pointed out that strengthening the construction of the socialist core value system needs to vigorously promote the national spirit and the spirit of the times; At the same time, it is necessary to carry out in-depth education in patriotism, collectivism and socialism in order to enrich the people's spiritual world, strengthen the people's spiritual power, and eventually gain people's recognition and social recognition. The 19th National Congress report pointed out: Culture is the soul of a country and a nation. Culture rejuvenates the country, and culture is strong. Without a high degree of cultural self-confidence and the prosperity of culture, there will be no great rejuvenation of the Chinese nation. We need to adhere to the path of developing socialist culture with Chinese characteristics, stimulate innovation and creativity in national culture, and build a strong socialist cultural power. It is necessary to focus on training the new people of the era who assume the responsibility of national rejuvenation, strengthen education guidance, practice cultivation, and institutional support, and give play to the guiding role of socialist core values in national education, the 
creation of spiritual civilization, and the production and dissemination of spiritual and cultural products.

The core value of socialism is the core of the socialist core value system. It embodies the fundamental nature and basic characteristics of the socialist core value system, reflects the rich connotation and practical requirements of the socialist core value system, and is a highly condensed and concentrated expression of the socialist core value system[1]. The core socialist values are the mainstream values of China under the socialist system. It is the observance of citizens 'value judgments and moral judgments, and it is an important value guarantee for cultivating socialist talents. We should actively cultivate and practice the core socialist values, consolidate the guiding position of Marxism in the ideological field, consolidate the common ideological foundation for the unity and struggle of the whole Party and the whole people, and promote the all-round development of the human being and lead the all-round progress of society. It is of great practical significance and far-reaching historical significance to gather the powerful positive energy for building a moderately prosperous society in all respects and realizing the Chinese dream of great national renewal. We need to integrate the core socialist values into the whole process of National Education, promote the incorporation of core socialist values into textbooks, classrooms and students 'minds, and strive to train socialist builders and successors who have developed in an allround way in morality, intelligence, physical integrity and beauty.

\section{OVERALl GOVERNMENT ADVOCACY PlanNING}

In September 2014, Prime minister Li Keqiang issued a call for "mass entrepreneurship and innovation" at the Summer Davos Forum. At that time, he proposed that a new wave of "mass entrepreneurship" and "grassroots entrepreneurship" should be set up on 9.6 million square kilometers of land, forming a new trend of "innovation" and "innovation for everyone."[2] Since then, he has frequently explained this keyword in the first World Internet Conference, the State Council executive meeting and various occasions. Every time he visited, he almost always met with the local young "creative". He hopes to inspire the nation's entrepreneurial spirit and innovation genes. In 2015, Prime minister Li Keqiang proposed in the government's work report: "Popular entrepreneurship, innovation."

The 2018 government work report states that in the past five years, innovation-driven development has yielded fruitful results. "Popular entrepreneurship and innovation" have flourished. The rapid rise of new drivers is reshaping the pattern of economic growth, profoundly changing the production and lifestyle, and becoming a new symbol of China's innovative development. As you know, the government and job seekers and the families behind them are "worried" about the difficult job market that millions of fresh graduates face every year. As one of the representative figures of the era's elite university students and "shrinking their hands" for innovation and entrepreneurship, how can ordinary people and mass groups innovate and start a business? The group of college students is the main force of innovation and entrepreneurship. From the central to the local governments at all levels, they have vigorously supported and issued relevant policies to encourage innovation and entrepreneurship. Therefore, how to grasp the correct direction of college students 'innovation and entrepreneurship and promote the development of the socialist cause with Chinese characteristics requires correct guidance by university party organizations on the values of college students' innovation and entrepreneurship, and guided by Xi Jinping's thinking of socialism with Chinese characteristics in the new era. Inculcating socialist core values and other related theories in entrepreneurship education and employment guidance related courses.

\section{IMPLEMENTATION IN COLLEGES AND UNIVERSITIES}

From a series of policy documents and measures of the central government, we can see that the Party and the state attach great importance to the work of college students 'innovation and entrepreneurship. As the main body of innovation and entrepreneurship education, colleges and universities have developed very rapidly. Many schools have mainly supported the establishment of entrepreneurship colleges or innovation and entrepreneurship laboratories, and set up related entrepreneurship courses to cultivate students 'innovation and entrepreneurship capabilities, and promote employment through entrepreneurship. Therefore, paying attention to the ideological education of college students 'innovation and entrepreneurship has great practical and theoretical significance in the practical path of the socialist core value system. It is also in line with the concept of "streamlining administration and delegating power" and "mass entrepreneurship and innovation" that the central government has frequently appeared in the report.

This paper aims to further train a large number of innovative and entrepreneurial elites through the practical path of innovation and entrepreneurship in the socialist core value system, and to create the backbone of a large number of socialist successors with Chinese characteristics. We should encourage college students to boldly reform and innovate their thinking, innovate and start their own businesses in the practice of socialist core values, and make use of all the conditions that are conducive to innovation and entrepreneurship provided on university campuses. As soon as possible to better integrate with the society.

In the perspective of innovation and entrepreneurship, colleges and universities have a solid carrier for the practice of cultivating innovative and entrepreneurial talents in the socialist core value system. This article's exploration of the practice path is conducive to the formation of a new talent concept in the whole society. The value of innovating and starting a business is helpful to promote the college students to understand and master the learning practice of professional theory, and through the influence of the ideal belief education and the common ideal of socialism with Chinese characteristics, guide the educatees to establish the goal of starting a business that meets the current social requirements of our country[3]. At the same time, it encourages college students to better and more solid study and research professional theory, improve the methods of college students 'entrepreneurship education, improve college students' entrepreneurship education courses, and 
enrich their diversified educational activities, eventually enriching and confirming the socialist core value system.

The author's school takes strengthening the education of undergraduate applied talents as the foundation of the school, and puts forward the construction goal of "building a centuryold school". The school is now facing the contemporary economic development and social needs, and under the guidance of the practical spirit of the socialist core value system, We will develop the educational and teaching model of "strengthening the foundation, broadening the profession, and paying attention to students 'entrepreneurship spirit, innovation ability, and practical ability training", and focus on training students to become all-round development of morality, intelligence, body and the United States. Solid foundation, high comprehensive quality, strong practical ability of applied professionals.

In response to the call of the State Council and the Ministry of Education to encourage college students to innovate and start their own businesses, we will effectively promote the cultivation of college students 'spirit of innovation and entrepreneurship, and improve their ability to innovate and start their own businesses and practice, echoing the goal of talents training in schools. We will vigorously advocate the education of socialist core values in the entrepreneurial experience stores of the school's entrepreneurship park, and strive to establish party members 'entrepreneurship demonstration posts, party activists' entrepreneurship demonstration posts, or entrepreneurship pioneer demonstration posts in the entrepreneurship park. At the same time, when the conditions are available, it is particularly important to build a comprehensive laboratory for innovation and entrepreneurship or establish an entrepreneurial college. In the course of this research, the Party members and Party activists of innovation and entrepreneurship students in relevant departments and departments are organized to hold talks and exchanges to further instill the concepts of reform and innovation in the core socialist values. Through them, they will guide more innovative and entrepreneurial students to practice the theory of socialist core values in the process of entrepreneurship, and actively cultivate undergraduate applied talents for innovation and entrepreneurship.

\section{STUDENTS' ACTIVE INNOVATION AND ENTREPRENEURSHIP}

The core socialist values are the concentrated embodiment of the contemporary Chinese spirit, condensing the common value pursuit of all the people. We need to focus on training new people in the era of national renewal, strengthen educational guidance, practice development and institutional support, and give play to the guiding role of socialist core values in national education, the creation of spiritual civilization, and the production and dissemination of spiritual and cultural products. The core socialist values are integrated into all aspects of social development and transformed into people's emotional identity and behavior habits [4].

The core socialist values lead college students to form a correct socialist entrepreneurship concept and entrepreneurship ethics. The concept of socialist entrepreneurship is the fundamental view and value judgment of people's entrepreneurship under the socialist system. It involves the fundamental value orientation of why to start a business, who to start a business, and how to start a business. What behaviors are desirable and what behaviors are undesirable in the process of starting a business; Those are good, those are evil. The concept of entrepreneurship directly affects the motivation and behavioral orientation of college students. The concept of socialist entrepreneurship and entrepreneurship is different from the entrepreneurial values of other social forms. The concept of socialist entrepreneurship is based on the socialist system, and it aims to vigorously develop social productive forces and achieve common prosperity.

Then, this means that in the analysis of this theoretical and practical path, the influence of college students 'recognition as the main representative of contemporary intellectuals can not be underestimated. Especially in the context of the current difficulties in the employment of college students, the practice of innovation and entrepreneurship in the new talent training model of colleges and universities confirms the need for the construction of the spirit of the times with reform and innovation at the core of the socialist core value system, and China is in a crucial period of comprehensively deepening reform. The voice of the 18th National Congress of the Communist Party of China(CPC), which clearly put forward the need to increase the support for the cultivation of innovative and entrepreneurial talents, has greatly encouraged universities to renew the training model for talents. The 19th National Congress of the Party further broadened the scope of innovative and entrepreneurial talents, emphasized the encouragement and protection of entrepreneurship, and encouraged more social actors to devote themselves to innovation and entrepreneurship. We will build an army of knowledgeable, skilled and innovative laborers, promote the spirit of model workers and craftsmen, and create a society of glorious labor and a professional atmosphere of excellence[5].

Under the guidance of the theory of innovation and entrepreneurship in the socialist core value system, the research in this paper aims at improving the employment rate of students in innovation and entrepreneurship in order to meet the requirements of practical training in various professional experiments, taking into account the actual conditions of schools and the needs of students in innovation and entrepreneurship. Establish a comprehensive training environment and a platform for innovation and entrepreneurship. In this experimental environment, students are trained in multi-professional and multi-skill interactive training. Students can conduct interactive operational operations and experiments with multiple identities on the comprehensive training platform, so as to master related entrepreneurial employment skills and increase their core competitiveness.

\section{CONCLUSION}

At present, China is in a crucial period of deepening reform and opening up. The 19th CPC National Congress has explicitly proposed to increase the training and support for innovation and entrepreneurship. Since entering the $21 \mathrm{st}$ century, innovation and entrepreneurship education has achieved universal consensus on the development of world 
education reform. Innovation and entrepreneurship education for college students in a broad sense refers to the idea of allround development, full development and integration of college students 'educational resources and social resources. The innovative educational activities carried out to college students with innovation and entrepreneurship as the core, enterprise as the carrier, and enterprise as the ultimate goal. Therefore, college students in the new era should, on the basis of paying attention to their own scientific and cultural knowledge, strive to practice the core socialist values. In the process of encouraging the relevant departments of the national government to encourage college students to innovate and start their own businesses, they should seriously consider how to integrate the two. We have learned not only scientific and cultural knowledge and socialist core values, but also learned the socialist core values to guide innovation and entrepreneurship and make due contributions to the country and society.

\section{REFERENCES}

[1] Zhang Zhixiong, Xu Haiyan, Zhang Yi. Ideological Misconceptions and Guiding Paths in College Students' Entrepreneurship Practice --- Also on the Integration of Socialist Core Values [J]. Innovation and Entrepreneurship Education, 2015 (4): 38-40.

[2] Liu Xiaogang. The Practical Path of Integrating Socialist Core Values into College Students' Ideological and Political Education [J].Chinese and Foreign Entrepreneurs, 2016 (10): 182-184.

[3] Sun Guosheng, Zhang Huili. On the Cultivation of Undergraduates' Entrepreneurial Values under the New Situation [J]. School Party Building and Ideological Education, 2015 (15): 88-89.

[4] Shen Wenqing, Sun Haitao. College students' Entrepreneurship values and entrepreneurship education [J]. college counselors, 2014 (2): 18-21.

[5] Shi Jing. Research on the cultivation of entrepreneurial values of agricultural college students [D]. Sichuan Agricultural University, 2014. 